\title{
IMAGO MUNDI - HANKISS ELEMÉR ÉPÍTÉSZETTEL KAPCSOLATOS GONDOLATAIRÓL
}

\section{IMAGO MUNDI - ELEMÉR HANKISS'S THOUGHTS ON ARCHITECTURE}

\author{
Fejérdy Tamás \\ építész, az ICOMOS elnöke, a kőszegi Felsőbbfokú Tanulmányok Intézete kutatója \\ info@iask.hu
}

\section{ÖSSZEFOGLALÁS}

Hankiss Elemér számára az építészet kérdéseinek vizsgálata nem elsődleges, csupán az embert körülvevő világgal kapcsolatos alaptézise okán releváns. Az építészet értelme így elsődlegesen nem a fizikai kereteket megalkotó építő tevékenységben, hanem az építészetnek az anyagiakon túlmutató, „mitologikus dimenziójában” fogalmazódik meg. A hangsúlyt egyértelműen az építészet nem anyagi vonatkozásaira helyezi. Ebben az összefüggésben az építészet, ha nem is egyetlen, de mással nem helyettesíthető eszközként jelenik meg annak az emberi törekvésnek a szolgálatában, hogy humanizálja, azaz a saját számára elfogadhatóan élhetővé tegye az őt körülvevő, alapjában idegen/ellenséges világot. Vagy legalábbis annak azt a térben (is) lehatárolt darabját, amelyet az építészeti mú abból mintegy leválaszt.

\section{ABSTRACT}

For Elemér Hankiss, the examination of the questions of architecture was no priority, it was only relevant for him in relation to his basic thesis, namely for the sake of the relations between human beings and their surrounding universe. The meaning of architecture, from this point of view, is not primarily related to physical frameworks but lies in the 'mythological dimension', which extends beyond material resources. The emphasis is clearly on the non-material aspects of architecture. Architecture, in this context, is seen as a tool designed to fulfil the aspiration of human beings to humanize, that is, to make the alien or hostile world surrounding humans liveable. Or, at least, the portion of the space that the architectural work separates from the endless universe.

Kulcsszavak: Hankiss, Kőszeg, épületek, építészet, szellemi közeg, dekoráció, emberi kaland, szimbólumok

Keywords: Hankiss, Kőszeg, building, architecture, intellectual medium, decoration, recreation, symbols 
Ismerve Hankiss Elemér sokoldalú érdeklődését, különféle diszciplínákban való jártasságát, s azt, ahogyan egy-egy általa fontosabbnak ítélt területen képes újszerü szempontokat felvetni, talán az sem lenne meglepő, ha egyszer csak felbukkanna egy eleddig ismeretlen, az építészet világával behatóan foglalkozó tanulmánya. Igazán nagyszerü lenne, ha egy ilyen rendkívüli „lelet” ismertetésével folytatódhatna ez az írás... Természetesen és sajnos nem erről van szó, mégsem érdektelen ebből az eddig talán még sohasem vizsgált szemszögből - építész szemmel - újraolvasni Hankiss Elemért. Írásaiban az ember alkotta környezetet legmarkánsabban megjelenítő épületekkel; a várossal mint jelenséggel; illetve néhány tudatosan kiemelt-kiválasztott épülettípussal kapcsolatos részletek lehetőséget adnak arra, hogy megismerjük az építészetre, annak sajátos szerepére vonatkozó elgondolásait.

Nagyszerü, de sajnos végül ki nem aknázott lehetőség merült fel e dolgok személyes megbeszélésére, azzal, hogy egy bizonyos időszakban rendszeresen útitársa lehettem Hankiss Elemérnek, $\mathrm{s}$ az út két végpontja közötti (még ma is több óra hosszat tartó) utat többször is együtt tehettük meg - vonaton vagy autóval utazva. ${ }^{1}$ Beszélgetéseink során sok minden előkerült, abban az időzítésben és formában, ahogyan azt az időbeosztása meghatározta - minden esetben hozott magával az utazás alatt elvégzendő munkát: többnyire elolvasni, megírni, lektorálni való szövegeket, kéziratot és így tovább. Amikor viszont a (mindig őáltala kezdeményezett) beszélgetésre került sor, teljes egészében arra összpontosított, és - természetesen - elsősorban kérdezett. Kérdezett a beszélgető partnertöl és saját magától is. Úgy tűnt, hogy számára a lét és általában a dolgok/jelenségek értelmének a keresés-kutatása, különféle oldalról és formában megfogalmazott kérdések körüljárása mindennél fontosabb. Kérdéseit úgy fogalmazta meg, hogy azok igazi érdeklődést mutattak, megtisztelve azzal a partnert, hogy láthatóan valóban érdekelte a válasz. A beszélgetés - bár Hankiss Elemérnél udvariasabb személyt nem lenne könnyü találni - számára nem volt pusztán udvarias időtöltés, hanem egy gondolati világ folyamatos alakításának eszköze. Beszélgetőtársát egyszerre tekintette (,használta”) tükörnek és ismeretforrásnak, annak a gondolati világnak a kiteljesítésében, amely érezhető módon mindig foglalkoztatta. Bekerülni ebbe a szellemi közegbe lebilincselő, megtisztelő és meghatározó hatású volt. Az ő témái köré rendeződő beszélgetések kitöltötték a rendelkezésre álló időt, ezért is alakulhatott úgy, hogy mire az építészettel kapcsolatos (általam természetesen igencsak óhajtott) „célzott” eszmecserére is sor kerülhetett vol-

\footnotetext{
${ }^{1}$ Ennek az írásnak azt a címet is adhattam volna, hogy Hankiss Elemér útitársa voltam. Ez, bár alapjában igaz, mégiscsak túlságosan szubjektív megközelítés lenne. Pedig valóban szó szerint értendő ez az útitárs viszony, mivel személyes találkozásaink, beszélgetéseink nagyrészt a Budapest-Köszeg útvonalra, a vonaton vagy autón megtett utak időtartamára sủrűsödtek, mondhatni korlátozódtak. Közös célpontunk fizikailag a kőszegi Európa Ház, intézményileg pedig az éppen akkor megszületőben lévő Center of Advanced Study for Innovative Thinking (CAS-FIT) volt.
} 
na, Hankiss Elemér halálával hirtelen-kegyetlen visszavonhatatlansággal örökre vége szakadt közös utazásainknak.

Történeti épületekkel foglalkozó, azok megőrzése és továbbéltetése iránt elkötelezett „müemlékes” építészként különösen érdekesnek találtam azt a nézőpontot, amellyel Hankiss Elemérnél, s elsősorban is $A z$ emberi kaland címü átfogó művében találkoztam. Megközelítésem, amellyel kizárólag az építészet területére összpontosítva látom és láttatom azt, amit ő mutatott meg, bizonyára erősen kritizálható. Ha nem is személyes, de szakmai szubjektivitással valószínüleg könnyedén megvádolható. A nagy egészből csupán valamely részletre korlátozódik, azt veszi nagyítóüveg alá, kockáztatva, hogy lényeges összefüggések veszhetnek el emiatt. Mentségnek talán nem elegendő, de magyarázó analógiaként mégis felhozható, hogy számos jelentős képzőmüvészeti alkotás (elsősorban festmények) esetében előfordult már, hogy - nem kisebbítve a „fenséges mü” egészének értékét - a kutatók figyelme valamely meghatározott szempont szerint mégis csupán a mü egy kiválasztott részletére fókuszált. Ilyen részletelemzések alapján derült fény sok fontos/hasznos/érdekes információra a mindennapi élet szokásaival, tárgyaival, viselettel, müszaki megoldásokkal - és így tovább - kapcsolatban. Ami viszont feltétlenül szem előtt tartandó, az az, hogy - függetlenül az adott mü (festmény) mely (és mely korból származó vagy mely korra utaló) valós vagy képzelt jelenet- vagy helyzetábrázolásától - a tanulmányozott részletek és az általuk hordozott információk mindig a mü keletkezési korára ${ }^{2}$ vonatkozó információval szolgálnak. ${ }^{3}$

\section{A VILÁG ÉS AZ ÉPITÉSZET VILÁGA - A HÁZ}

Érthető módon Hankiss Elemér számára az építészet nem elsődleges tárgya a vizsgálódásnak, csupán abból az aspektusból és annyiban foglalkozik vele, amennyire az embert körülvevő világgal kapcsolatos alaptézise okán releváns. E megközelítés szerint az ember egy számára idegen, „nem kompatibilis” világban kell, hogy megmaradjon, éljen, és ha talán csak átmenetileg is, de otthon érezhesse magát. Az építészet értelme ezért számára elsődlegesen nem a fizikai kereteket megalkotó épító tevékenységben, hanem az építészetnek az anyagiakon túlmutató, „mitologikus dimenziójában” (Hankiss, 2014, 131.)4 fogalmazódik

\footnotetext{
${ }^{2}$ Vö. a bibliai jelenetekben, például a Passió-ábrázolásokon megjelenő törökös ruházatok esetével.

${ }^{3}$ Utólagos igazolásaként csak később realizálódott, hogy Az emberi kaland 2014-es kiadásának címlapján szereplő, Brueghel-képekből készített montázs is él a kiemelt-kinagyított részletek bemutatásának az eszközével. [F. T.]

${ }^{4}$ Ebben az összefüggésben ugyancsak ide tartozhatnak a mü előző, 3. fejezetéből a „kert” tematikával foglalkozó gondolatok is.
} 
meg. Nyilvánvaló módon nincs szándékában kisebbíteni az építészet mint 'építés', azaz a fizikai-védelmi funkciót létrehozó emberi („müszaki”) tevékenység jelentőségét, amely ugyancsak nem lebecsülendő produktuma az embernek az építés/ építészettörténet kezdeteitől napjainkig. A spirituális-mitologikus vonatkozásokat abból a szempontból tekinti meghatározónak, hogy azok miként szolgálhatnak - ha nem is egyetlen, de mással nem helyettesíthető eszközként - annak az emberi törekvésnek a beteljesítésére, hogy az ember humanizálja, azaz a saját számára elfogadhatóan élhetővé tegye az ôt körülvevő, alapjában idegen/ellenséges világot. Vagy legalábbis annak azt a térben (is) lehatárolt darabját, amelyet az építészeti mü abból mintegy leválaszt.

Az épületbelsőnek a külső megjelenéshez képest hangsúlyosabb tárgyalása is aláhúzza, hogy nem építészettörténeti megfontolások irányítják a gondolatokat. Ez nyilvánvalóan azzal van szoros összefüggésben, hogy éppen a világból leválasztott, elkülönített tér az, amely az emberi léptékhez, emberi igényekhez igazított megoldásként szolgálja azt a célt, hogy legalább a közvetlen környezet legyen otthonos az idegen világban. Ebben a gondolatmenetben tehát nem az az elsődleges, hogy mit mutat kívülről egy épület, hanem az, hogy körülvesz. Más szavakkal, ez az a mesterségesen létrehozott véges-arányos méretü térrész, amely megvédi az embert a külső világtól, annak mind a materiális, mind pedig a nem anyagi természetủ ellenséges hatásaitól. Teszi mindezt úgy, hogy közben azért mégis és tudatosan része marad a kozmosznak, sajátos, ember alkotta mikrokozmosz a makrokozmoszban. Szinte már ellentmondásos, ahogyan azzal szembesít Hankiss írása, hogy ez a nagyon is emberi oldalról történő megközelítés milyen módon és mértékben igyekszik tükrözni, megjeleníteni vagy talán igazodni a környező világ általa felismert (kozmikus) jelenségei alapján leszürt, absztrakció szintủ elemekhez. Az univerzum leképezésére való törekvésként értelmezhető ez. Vagyis - bár ez nincs így kifejtve - úgy akarja az ember a saját elkülönített kis világát létrehozni, hogy abban mégis az univerzum része maradjon. ${ }^{5}$ Ehhez a kapcsolódási, igazodási törekvéshez kötve esik szó az alapvető geometriai formák - a négyszögletü/négyzetes és a kör - szimbolikus szerepéröl. Különféle népek és történeti korok ezt tanúsító, meglepő azonosságokat felmutató hagyományait egybevetve állapítja meg, hogy ,,együtt van a szögletes és a kerek alakzata, amely együttesen a világmindenséget jelképezi”.

\footnotetext{
${ }^{5}$ Hankiss Campbellt* idézi: „,...az ember és a világ közötti alapvető harmóniára utal, és emlékeztet a tökéletesedés rejtett életútjára”. (Hankiss, 2014, 134. 110. lábjegyzet: Campbell, Joseph: The Hero with a Thousand faces. Princeton, Princeton University Press 1968 [1949], page 385.)

*Joseph Campbell (1904-1987) amerikai író, esszéista, vallástörténész.
} 


\section{A VILÁG ÉS AZ ÉPITÉSZET VILÁGA - A VÁROS}

Az univerzumból kihasított, az idegen világnak kiszolgáltatott ember védelme céljából körülhatárolt tér következö, közösségi léptékü megvalósulása a város. Ennek a védelmi „fokozatnak” ugyancsak kiemelten fontos a szimbolikus funkciója, éppen azzal, hogy a környezetétől határozottan elkülönülő struktúrát hoz létre. Bár ez a határozott elkülönülés nyilvánvaló módon nem választható el a fizikai-védelmi funkciótól, az eltérő korokban különféle fokozatú és hatékonyságú városfalak szerepétől, ami igazán figyelemre méltó ebben a megközelítésben az az a jelentős minőségi különbség, ami azzal írható le, hogy ,az emberi értelem rendje érvényesül majd, és kizárja a vadont: az erdőt, az óceánt, az idegen világ kaotikus és veszélyes eröit" (Hankiss, 2014, 138.). Nem foglakozva a továbbiakban a város archetípusait áttekintő részletekkel, hanem a városról szóló rész záró bekezdéséhez ugorva súlyos, továbbgondolást iniciáló gondolatokat találunk. Utalást arra, hogy „...mindazoknak az emberi törekvéseknek az ellenére, amelyek meg akarták védeni a városokat, az élet szent és védett területeit, az idegen világ erőit sohasem sikerült teljesen legyőzni”. Vizsgálódásunk számára a városok sorsa szempontjából nem az az egyébként kissé meglepő dolog érdekes, hogy „idegen világ” hatásainak a következményeit sorolva Hankiss ezen a helyen nem tesz különbséget a természeti erők (univerzum?) és az ember okozta katasztrófák között. A pusztulási és újjáalkotási periódusok egymást követő szekvenciáit sorolva, egyrészt azt érzékelteti, hogy az univerzum és az ember közötti viszony megoldását nyújtó „mitologikus” város meg-megújuló, de alapjában eredménytelenségre ítélt törekvés - másrészt, a mai urbanisztikai irányzatokat felvillantva egyfajta, lényegében csak a kevesek számára elérhető megoldásra utal (Hankiss, 2014, 141.). Részletes kifejtés nélkül ugyan, de nagy biztonsággal rátapintva ezzel a jelenkori urbanisztika két jellegzetes kihívására. A horizontálisan nagy kiterjedésű földszintes kertváros az egyik irányzat, amely (térbeli és fenntarthatósági) korlátainál fogva nyilvánvalóan nem válhat általánossá; a felhőkarcolók vertikális világa a másik irányzat (a maga anyagi, technikai, fenntarthatósági, biztonsági stb. korlátaival) - valójában egyik sem alkot várost az általa használt tradicionális-mitologikus funkció tekintetében. Messze vezetne annak a gondolatnak a részletesebb végigvitele, amely a katasztrófák, pusztulási periódusok utáni megújulás kérdésével foglalkozik. Itt csupán azt a vonatkozást érdemes kiemelni, amely szorosan kapcsolódik az építészet, illetve a város mitologikus dimenziójához. Ez pedig nem más, mint az a szinte irracionális jelenség, amellyel egy-egy konkrét alkotás, hely, helyszín ismételt megújításához ragaszkodik az ember - egyénileg és közösségileg egyaránt. (Ez a jelenség napjainkban ismét és erőteljesen jelen van az építészet/müemlékvédelem/örökségvédelem elvi és gyakorlati kérdéseivel foglakozó szakmai körökben éppúgy, mint a döntéshozók, illetve helyi közösségek terveiben, ezért alább még lesz szó a történeti épületek- 
kel kapcsolatos rekonstrukciós törekvésekről.) Az épített környezeti elemek, az épített örökség ${ }^{6}$ szerepe a közösségek, társadalmak rezilienciája vonatkozásában akár úgy is tekinthető, mint sajátos igazolása mindannak, amit Hankiss Elemér állít az ember alkotta környezeti elemek tágabb, nem csupán materiális szempontból értelmezett funkciójáról (vö. Fejérdy, 2015).

\section{A VILÁG ÉS AZ ÉPITÉSZET VILÁGA - A TEMPLOM ÉS A KATEDRÁLIS}

Ezzel a tudatosan kiválasztott épületfajtával még inkább megvilágítja, példákkal támasztja alá azt az állítását, hogy „Az emberek mindent elkövettek annak érdekében, hogy ezeket a mikrokozmoszokat mindenáron és minden eszközzel megvédelmezzék" (Hankiss, 2014, 142.). Az Isten és az ember kapcsolatával ${ }^{7}$, a szent és a profán viszonyával és elkülönítésének örök törekvésével kapcsolatos gondolatsorok ismét csak rávilágítanak néhány, az elözőkben már részben érintett tételre. Ezek közül az egyik a hely (elhelyezkedés, helyszín) jelentőségének hangsúlyozása. A hely korábban döntő meghatározást jelentő szerepéből hosszú évszázadokra háttérbe szorult. A csupán néhány évtizedre visszatekintő múemlék versus kulturális örökség paradigmaváltás egyik hozadékaként éppen napjainkban válik, vált megint elismert értéktényezővé $a$ hely (önmagában is), nem utolsósorban a nem európai kultúrák ('́gy különösen az ausztráliai öslakosok) hagyományos értékeinek a tanulmányozásával és elismerésével. ${ }^{8}$

A másik, napjaink építészeti gondolkodását tekintve hasonlóan időszerü téma a geometriai formák, a matematikai megfelelések - általánosságban összefoglalva az építész által az épülete révén a világból merített „,szabályok” alkalmazása, és az arra visszasugárzó rendteremtés szándékának kiemelése, amelyet Hankiss megint csak az univerzumhoz való emberi viszony oldaláról vizsgál. Ezzel ismét valami lényegesre mutat rá. Korunk vitathatatlanul pluralista építészetében - kis túlzással - gyakorlatilag mindenféle irányzat és mindenféle irányzatnak a „neo” vagy éppen „neo-neo” változata megtalálható, ami viszont közös vonásnak tekinthető, az talán éppen ezzel az univerzális renddel kapcsolatos, melyhez így vagy úgy - igazodva hozzá vagy tagadni próbálva azt - viszonyulnia kell az építésznek.

A történeti épületek kapcsán pedig azt is hozzátehetjük, hogy az építészeti alkotások megértésében, esetleg a töredékes mivoltukból való visszaállításuk megala-

${ }^{6}$ Ez a kifejezés itt tágabb, teljes értelmében, nem csupán a 'műemlék' tehát a (jogilag is) védett épített objektumokra vonatkoztatva használatos.

${ }^{7}$ Építészeti vonatkozásban erről is szól Frans Jeursen holland filozófus, középkorral foglalkozó történész és művészetkritikus előadása (Jeursen, 2010).

${ }^{8}$ Vö. Az ICOMOS Ausztrál Nemzeti Bizottság Burra Kartája a kulturális jelentőségű helyek védelme tárgyában (The Burra Charter, 1980). 
pozásában egészen különleges jelentősége van annak, hogy „visszafejtve” a létrehozásukkor alkalmazott szerkesztési elveket, szabályokat, a lehetö leghitelesebb megoldáshoz lehessen eljutni. ${ }^{9}$ Ugyanakkor nem szabad megfeledkezni ennek a módszernek az alkalmazási korlátairól sem - amelyek, egyáltalán nem meglepő módon, éppen a Hankiss által minduntalan hangoztatott „,szimbolikus-mitologikus" dimenzióval vannak összefüggésben, ugyanis minél inkább annak a hordozója egy épület, annál inkább kötődik a szerkesztési szabályokhoz. Nem véletlen, hogy a görög-római templomok kötött, modulalapon szerkesztett oszloprenddel épült épületei esetében jól alkalmazható a (kiegészítéses) anasztilózisz módsze$\mathrm{re}^{10}$, ugyanez viszont aligha mondható el például egy (mégannyira szabályosnak is látszó) középkori vár esetében. A katedrálisok építészete egyszerre tanúskodik a szerkesztési szabályok meglétéről és azok egyéni, mủvészi adaptációjáról. A keretek, a formakincs azonossága egyáltalán nem vezetett uniformizált alkotások létrehozásához - igazán érdekes és a továbbgondolást inspiráló lett volna megtudni Hankiss Elemértől, hogy erről az „egység a sokféleségben” jelenségről az ő tézisei szempontjából volt-e, lehetett-e bármilyen jelentősége?

\section{A VILÁG ÉS AZ ÉPITÉSZET VILÁGA - A BEVÁSÁRLÓKÖZPONT}

Jellemző és elgondolkodtató, ahogyan az ember és az öt körülvevő (idegen) univerzum viszonyát vizsgálva Hankiss váltogatja a szent és a profán oldaláról történő megközelítést. Ennek a különböző oldalakról történő, nem is annyira párhuzamos, hanem sokkal inkább egyidejü értelmezésnek megvan az előnye és bizonyára a hátránya is. Ez a kettőslátás leginkább talán a Káosz és kozmosz: ma átfogó címen belül szereplő, egymást követő részletekben: A bevásárlóközpont, Transzcendentális karnevál, A sátán birodalma és $A$ negatív mitosz szövegekben érhető tetten. Építész számára meglepő ezeknek az épületeknek az a metamorfózisa, sőt, kisebb képzavarral élve: az a fajta apoteózisa, amely az építészek nézőpontjából korántsem számít igazán vonzó feladatnak, sokkal inkább (lehet, hogy nem rosszul fizető, de mégiscsak) a középszerütől alig eltérő rutinmunkának. Teljesen világos, hogy a felértékelődésük oka egészen más síkon keresendő, illetve található meg. Mégis: Hankiss gondolataiból kiolvasható az építészek, épületek és

${ }^{9}$ Vö. például Szakál Ernő kőszobrász-restaurátor művésznek a töredékesen fennmaradt építészeti alkotások - visegrádi királyi palota kútházai, siklósi vár gótikus zárt erkélye stb. munkáival (Szakál, 2007).

${ }^{10}$ A szétesett építőelemek újbóli összerakása föleg a faragott kőből alkotott antik épületek esetében alkalmazott, alkalmazható. A hasonlóan állandó, szent szabályokon alapuló ázsiai fatemplom, illetve palotaépítészet alkotásainak „rekonstrukciója” éppen emiatt tekinthető az esetek túlnyomó többségében hitelesnek, szemben az ,individualista” (adott esetben a rendeltetésnek és a környezetbe való illesztésnek amúgy sokkal inkább megfelelö) európai építészeti alkotásokkal. 
főleg a belső terek kialakítóinak szóló komoly üzenet, rámutatva arra, hogy - nem utolsósorban a megelőző korszakok súlyos szimbólumainak kiüresített, leegyszerüsített, néha már-már parodisztikus alkalmazásával - miként silányodhat el az Építészet (nagy kezdőbetűvel) eredeti, az ember és az őt körülvevő univerzum közötti harmónia megteremtését-megjelenítését szolgálni hivatott küldetése. „Amorális" közeget eredményező pótmegoldás létrejöttében válhat ezzel egy negatív erő cinkosává az építész - olvashatjuk ki ugyanabból a szövegből, amely néhány bekezdéssel korábban szinte szuperlatívuszokkal érzékelteti a bevásárlóközpontok már-már transzcendentális atmoszféráját.

Az építészeti vonatkozásoktól eltekintve is elgondolkoztató, hogy az egész elemzéssorozaton átvonuló kettősségben Hankiss explicit módon nem foglal egyértelmüen állást, csupán az ennek a szövegrésznek a - már megszokott módon kérdésként és nem állításként megfogalmazott - lezárásából lehet valószínú álláspontjára következtetni. Arra, hogy a fogyasztást a középpontba állító megoldással az emberek „....akarva-akaratlan az idegen világ kényének és kedvének szolgáltatták ki magukat; hogy majd jobban, mint valaha, »az élet ürességének rettenetét« kell átélniük; azt, ami elől és amiből menekülni akartak". Ezen a ponton, átmenetileg kilépve a választott (építészeti) téma köréből, nem lehet nem visszaidézni azt a bevezetőben említett „útitársi beszélgetéseink” során egyre inkább megerősödő benyomást, hogy a nagyon korrekten és mindig több oldalról megfogalmazott kérdések sokasága mintha valamilyen módon arra is szolgált volna Hankiss Elemérnél, hogy késleltesse azt, hogy egy konkrét választ kelljen érvényesnek, horribile dictu véglegesnek elfogadni. Az emberi kaland olvasása, újraolvasása során is fel-felmerül(het) az olvasóban, hogy: kérdései mögött el is tud rejtőzni a szerző?! Kétségtelenül negatívabb, de minden sértő szándék nélküli megfogalmazásban: mintha saját maga is visszahőkölne attól, hogy az annyira keresett válasz... egyszer csak véglegessé váljon. Nem bizonytalanságból, még kevésbé gyávaságból (amitől aztán tényleg semmi sem állt távolabb tőle!) alakulhatott ez így (ha valóban így volt), hanem abból, a beszélgetésünk során általa konkrétan megfogalmazott, alighanem nagyon is jellemző megközelítéséböl, hogy: milyen unalmas lehet, lenne, ha - elérkezve a bizonyossághoz - már nem lehetne kérdezni...

Visszatérve a közvetlenül a bevásárlóközponthoz - mint épülethez - kapcsolódó tematikához, érdemesnek látszik közelebbről rátekinteni az épületet díszítő, annak atmoszférateremtő hatását fokozandóan alkalmazott dekorációra is. „Nemes” anyagok alkalmazásáról, kizárólag az esztétikai-érzelmi hatás kiváltását célzó díszek, díszítések halmozásáról olvashatunk - legyenek azok állandó tartozékai az épületnek, vagy csupán ideiglenes-szezonális célokat szolgáljanak: közös céljuk a mai, a vizualitás irányába kilendült környezet-érzékelés keretében egyfajta „varázslat”, valamiféle transzcendentalitás érzésének kiváltása. Azt az üzenetét, hogy itt a lényegestől a külsődleges felé mozdult el az épített terek 
megjelenése, éppen azzal erősíti a szerző, hogy az előző, a történeti építészet szerepével foglalkozó szövegrészekhez képest ilyen erőteljes hangsúllyal szól a dekorációról.

\section{A (TÖRTÉNETI) ÉPÍTÉSZETBEN ALKALMAZOTT DEKORÁCIÓRÓL}

...ugyanis csupán kétféle összefüggésben (és viszonylag röviden) esik szó, miközben azt lehetne gondolni, hogy annak bizony jelentős szerepe lehet (volt is) abban, hogy az építészet mitologikus funkciója az épület külső megjelenésében is megjelenjen, s müködjön a nem anyagi funkció. Az egyik terület ez esetben is az épületbelsők világa, ahol gyakorlatilag szinte elválaszthatatlanná válik az építészet és a társművészetei - szobrászat, festészet, üvegmüvészet. Talán ott lehetne megvonni a határt (ha egyáltalán szükséges), hogy melyek azok a társművészeti alkotások, amelyek elválaszthatatlanul hozzátartoznak az építészeti mühöz.

A másik terület, amellyel viszont - talán kicsit meglepő módon is - nagyobb terjedelemben foglalkozik Hankiss az e tanulmány alapjául vett múvében, egy ugyancsak sajátos díszítési forma, az arabeszk világa. Végül is igazat lehet adni gondolatmenetének, amelyben az arabeszkben megjelenő absztrakció jelentőségét ünnepli, állítva, hogy „Az emberi képzeletnek és müvészetnek ez az egyik legnagyobb diadala az idegen világ fölött.” (Hankiss, 2014, 150.) Ugyanakkor viszont kisebb hiányérzet marad a történeti épületekkel foglalkozó olvasóban: az épületek szimbolikus-mitikus funkciója és az azt szolgáló dekoráció vonatkozásában több mindenről eshetett volna még szó, gondolva itt például a kultikus épületek „bajelhárító” (apotropaikus) díszítéseire, vagy éppen a középkori templomok különféle biblia jeleneteinek az épületen belüli, hagyományosan kialakult helyére.

\section{BEFEJEZÉSÜL - NÉHÁNY GONDOLAT TÖRTÉNETI ÉPÜLETEK REKONSTRUKCIÓJÁRÓL"}

A müemlékek - tágabb, mai kifejezéssel: a kulturális örökség elemei, azon belül is az épített elemek megörzésével kapcsolatos elvek és gyakorlat természetesen ugyanúgy változik az időben, mint ahogyan az élet minden más területén is történik. Vannak azonban vissza-visszatérő kihívások, és ezek közé tartozik az is, hogy miként kell/lehet viszonyulni a történeti, szimbolikus vagy identitást

\footnotetext{
${ }^{11}$ Jelen írás szerzőjének az iASK intézményi program keretében folyamatban lévő 2017. évi kutatási témája: „New Technical and Social Approaches in the Preservation of the (Built) Cultural Heritage - Analysis of the New Wave of Reconstruction".
} 
hordozó jelentőséggel bíró, de valamilyen esemény miatt részben vagy egészben elpusztult múemlékekhez, azok esetleges visszaállításához, rekonstrukciójához.

Úgy tartozhat ez ide, hogy Hankissnak Az emberi kalandban az építészetre, annak misztikus-szimbolikus jelentőségére-küldetésére vonatkozó gondolatai mindenképpen hozzájárulnak annak a megértéséhez, hogy miért is lehet olyan fontos valaminek az újraalkotása, olyan épületeknek is, amelyre ráadásul mindennapi, pusztán fizikai értelemben vett rendeltetésük miatt igazából nem is volna szükség. Érdemesnek, sőt, ettől kezdve szükségesnek látszik minden ilyen újrateremtési szándék esetében megvizsgálni, hogy miben rejlik az a hiány, hol és miben jelentkezik ,az idegen világtól” az embert (elsősorban nem fizikailag) megóvó védőháló folytonossági hiánya, amelyet esetleg valóban csak ezzel a gesztussal lehet befoltozni. A rekonstrukción ${ }^{12}$ problematikájának részletes taglalása természetesen nem tárgya ennek az írásnak, de még egy, ugyancsak Hankiss Elemér gondolataira épülő, azokból leszűrhető kiegészítő szempont megemlítése mégsem hagyható ki. Nevezetesen az, hogy a rekonstrukciónak sem szabad hamisan csillogó pótléknak lennie (mint a bevásárlóközpontok esetében), azaz ha az valóban indokolt és szükséges, akkor olyannak kell lennie, amely az eredeti „mitologikus rendeltetés" továbbéltetését, az eredeti üzenet továbbadását szolgálja.

\section{IRODALOM}

Fejérdy T. (2015): Cultural Heritage as a Basis for Resilience - A Reserve for the Regeneration of Historical Cities. In: Miszlivetz F. (ed.): Creative Cities and Sustainability. Savaria University Press

Hankiss E. (2014): Az emberi kaland-Egy civilizációelmélet vázlata. 5. bővített kiadás, Budapest: Helikon Kiadó

Jeursen, F. (2010): Miről szól az épitészet? Előadás, 2010. november 30. (ford. Gaschler-Gyeviki

N.) http://epiteszforum.hu/nyomtatas/mirol-szol-az-epiteszet

Szakál E. (2007): Köfaragók mühelytitkai. [Budapest] Magyar Kőszövetség

The Burra Charter (2011): The Australia ICOMOS Charter for Places of Cultural Significance. In:

Fejérdy T. (szerk.): Karták Könyve. 2. kiadás. Budapest: ICOMOS Magyar Nemzeti Bizottság, http://www.icomos.hu/data/documents/documents/2/d/1/2d1be8f3a882b152d52fe689644a8ace.pdf

\footnotetext{
${ }^{12}$ A rekonstrukció fogalmát nem az EU-támogatású projektek szóhasználatában, hanem a Velencei Karta (1964) által definiált ételemben kell érteni.
} 